\title{
MENINGITE POR CRIPTOCOCCUS NEOFORMANS COMO CAUSA DE FEBRE PROLONGADA EM PACIENTE COM AIDS
}

O paciente, um indivíduo de 38 anos do sexo masculino, apresentava como comportamento de risco o uso de drogas injetáveis há 10 anos. Há um mês havia realizado sorologia para os vírus HIV e HCV, ambas positivas. Não havia apresentado intercorrências prévias associadas à infecção pelo HIV, exceto a presença de candidíase oral. No momento da admissão, não havia realizado dosagem de CD4 e carga viral, tão pouco iniciado tratamento anti-retroviral.

Há 10 dias da admissão, iniciou febre alta $\left(38,5^{\circ} \mathrm{C}-39,0^{\circ} \mathrm{C}\right)$, vespertina, acompanhada por sudorese noturna. Apresentava também náuseas e vômitos diários, pós-alimentares, e emagrecimento de 10\% do seu peso neste período. Ao exame físico apresentava-se em regular estado geral, corado, emagrecido, desidratado $+++/ 4$, com hipotensão ortostática: PA 90/40 mmHg em pé, e 100/60 $\mathrm{mmHg}$ deitado. À oroscopia, apresentava candidíase oral. O baço não era palpável, porém o espaço de traube estava ocupado, sugerindo o aumento do tamanho do órgão.

$O$ paciente foi investigado com exame radiográfico do tórax, hemograma, urina tipo I, hemoculturas para bactérias, fungos e micobactérias, coprocultura, urocultura, parasitológico de fezes com pesquisa de isóspora e criptosporídium, e endoscopia digestiva alta. Apresentava importante linfopenia, com apenas 53 I linfócitos/ mm3 no sangue periférico. Apresentava discreto aumento de transaminases hepáticas, que foi atribuído à infecção crônica pelo VHC. Foi isolado, em amostra de hemocultura o Criptococcus neoformans. 0 parasitológico de fezes revelou a presença de oocistos álcool ácido resistentes, sugestivo de criptosporídium. Foi realizada expansão volêmica com soro fisiológico e medicado com Fluconazol (400mg por dia, por via oral) e sulfametoxazol/trimetroprin (1600/320mg por dia, por via oral), evoluindo assintomático. Recebeu alta no terceiro dia de internação.

Foi acompanhado em serviço especializado em moléstias infecciosas, sendo realizada contagem de células CD4, que evidenciou a presença de apenas 49 cel CD4 / mm3, e PCR qualitativo para o vírus da hepatite $C$, que resultou positivo. Apesar de não apresentar sinais e sintomas meníngeos ou sugestivos de hiperten- são intracraniana, foi realizada punção lombar, que evidenciou aumento discreto de leucócitos e tinta da china positiva. A cultura e o látex para fungos confirmaram a presença do Criptococcus neoformans no líquor. Medicado com anfotericina $B$, apresentou cultura para fungos negativo dois meses após o primeiro líquor, porém a tinta da china persistiu, demonstrando a presença do Criptococcus. Foi mantido com fluconazol $400 \mathrm{mg}$ por dia como tratamento de manutenção, e continua em acompanhamento regular naquele serviço. Também foi iniciado esquema antiretroviral de alta potência (HAART), com zidovudina, lamivudina e efavirenz.

As febres prolongadas e de difícil diagnóstico são freqüentes nos indivíduos infectados pelo HIV. Doenças como a meningite criptocócica, que geralmente apresentam-se com envolvimento de órgãos e sistemas, podem apresentar-se com febre prolongada e sintomas inespecíficos no paciente com imunossupressão, especialmente nos estágios mais avançados da Aids. O uso de esquemas anti-retrovirais de alta potência tem diminuído a incidência de infecções oportunistas nos pacientes com Aids, mas aparentemente não tem modificado a etiologia atribuível a estes casos. As micobacterioses predominam como agentes preferenciais destes quadros. Estudo recente em nosso meio confirma esta tendência: em 55 casos de febre de origem indeterminada em pacientes com Aids, a maioria foi atribuída à infecção pelo Myicobacterium tuberculosis. Neste estudo, 5\% dos casos foram atribuídos à meningite criptocócica. A criptococose acomete os indivíduos com Aids, preferencialmente quando os níveis de CD4 estão abaixo de 100 células/ mm3. A manifestação mais freqüente da criptococose é o acometimento do sistema nervoso central, como meningoencefalite subaguda ou crônica. Com menor freqüência, se manifesta com sintomas respiratórios ou cutâneos. Outras manifestações são muito mais raras. O início da doença criptococócica na Aids geralmente é insidioso. O tempo mediano entre o início dos sintomas e o diagnóstico da doença é em geral de 30 dias. Por este motivo é recomendada a inclusão da pesquisa de antígeno para o Criptococus neoformans na investigação do paciente com
Aids e febre prolongada. No caso relatado, o diagnóstico foi realizado por hemocultura para fungos, análise do líquor pelo método da tinta da china, látex para Criptococus neoformans e cultura para fungos com boa resolutividade.

- fluconazol foi inicialmente utilizado para o tratamento da meningite criptococcócia nos pacientes com Aids devido à sua excelente farmacocinética no líquido céfaloraquidiano, entretanto, antes da epidemia de Aids, a terapia padrão para a meningite criptocócica era a administração de anfotericina $B$ e flucitosina por quatro a seis semanas. Atualmente, tanto o fluconazol como a anfotericina $B$, e a flucitosina são aceitos para o tratamento da meningite criptococócica na Aids. O maior estudo prospectivo sobre a meningite criptococócica na Aids não encontrou diferença no prognóstico entre o grupo que recebeu tratamento com anfotericina $B(0,4 \mathrm{mg} / \mathrm{kg}$ dia $)$ e o grupo que foi tratado com fluconazol, com menos de $50 \%$ de negatividade das culturas do líquido cefalo-raquidiano na segunda semana de tratamento. A mortalidade foi de $8 \%$ no grupo tratado com anfotericina $B$, contra 15\% no grupo do fluconazol. Entretanto, os resultados de trabalhos menores sugerem que a anfotericina $B$ administrada em doses maiores $(0,7$ a $0,8 \mathrm{mg} / \mathrm{kg}$ dia), tanto isoladamente como com flucitosina, pode ser superior aos triazólicos orais. $O$ itraconazol parece ser menos eficaz do que o fluconazol para o tratamento da meningite criptococócica na Aids. Devido ao risco de desenvolvimento de resistência à flucitosina, esta não é utilizada isoladamente, sendo sempre associada ao uso de anfotericina B ou fluconazol. Uma combinação de fluconazol com flucitosina parece ser superior ao uso de fluconazol isoladamente, entretanto, o regime combinado foi mais tóxico que a monoterapia com fluconazol. Recentemente, as formulações lipídicas de anfotericina $\mathrm{B}$ têm sido testadas para meningite criptococócica, e podem apresentar alguma vantagem sobre a anfotericina $B$ convencional quando utilizada isoladamente, e provavelmente em associação com flucitosina.

Rafael Mariano Gislon da Silva Hospital São Vicente de Paulo Faculdade de Medicina de Jundiaí 